\title{
Granulated and Biosolid Fertilizers on the Quality of Schinus terebinthifolius Raddi Seedlings
}

\author{
Francisca Alcivania Melo Silva ${ }^{1}$ (D), Giovana Margueri Nunes ${ }^{1}$ (D), \\ Jair Augusto Zanon² (D), Roberto Lyra Villas Bôas ${ }^{3}$ (D), \\ Reginaldo Barboza Silva ${ }^{1}$ (D) \\ ${ }^{1}$ Universidade Estadual Paulista "Julio de Mesquita Filho" - UNESP, Registro/SP, Brasil \\ ${ }^{2}$ Universidade Federal do Paraná - UFPR, Curitiba/PR, Brasil \\ ${ }^{3}$ Universidade Estadual Paulista "Julio de Mesquita Filho" - UNESP, Botucatu/SP, Brasil
}

\begin{abstract}
The objectives of this study were to evaluate substrates produced from the peach-palm agroindustry waste and sewage sludge as a source of nutrients for the production of Brazilian Peppertree seedlings (Schinus terebinthifolius Raddi), and to compare the performance of these substrates under various levels of slow release fertilizer for this species. Four levels of fertilizer were tested $\left(0,2.0,4.0\right.$ and $\left.6.0 \mathrm{~g} \mathrm{dm}^{-3}\right)$ in three types of substrates: BIOCPI $=$ Sewage sludge + Peach-palm bark $(1: 1 \mathrm{v}: \mathrm{v})$; BIOCPII = Sewage sludge + Peach-palm bark $(1: 2 \mathrm{v}: \mathrm{v})$ and BIOCPIII = Sewage sludge + Peach-palm bark (1:3 v:v). Plant height, stem diameter, dry matter (shoot and root), height/diameter ratio, Dickson quality index and $\mathrm{N}, \mathrm{P}, \mathrm{K}, \mathrm{Ca}, \mathrm{Mg}$, and $\mathrm{S}$ contents in the shoot were measured. The use of the substrates BIOCPII and BIOCPIII proved to be viable for the production of Brazilian Peppertree seedlings. Doses above $4.0 \mathrm{gdm}^{-3}$ of granular fertilizer are recommended for better results.
\end{abstract}

Keywords: macronutrients, nurseries, sewage sludge, substrate, Brazilian Peppertree. 


\section{INTRODUCTION}

The Brazilian Peppertree (Schinus terbinthifolius Raddi) belongs to the Anacadiaceae family. It is a pioneer species, native to Brazil, with great potential for economic and ecological exploitation (Lenzi \& Orth, 2004). It has high ecological plasticity, rapid growth and fruit production for avifauna. Hence it can occupy different types of environment and plant formations (Fleig \& Klein, 1989), and is commonly used for recovery processes in degraded areas and riparian forests.

The production of seedlings of species like the Brazilian Peppertree demands low-cost and quality substrates in a large quantity. The substrate exerts a marked influence on the architecture of the root system and on the nutritional status of plants, intensely affecting the seedling quality. For the composition of specific materials, it is necessary to select products with appropriate characteristics for each species, rationalizing costs without compromising the seedling quality (Caldeira et al., 2011).

Sewage sludge is a waste produced in large quantities from treatment plants, which does not yet have a destination that allows for its efficient reuse. For the most part its final destination is a sanitary landfill. The agricultural use of this material is regulated by law, prescribed by Resolution No. 375/2006 of the National Council for the Environment - CONAMA (Brasil, 2006). The resolution defines criteria and procedures for the agricultural use of sewage sludge generated in sewage treatment plants and of its by-products.

The sludge richness associated with other structuring components such as rice hulls, wood sawdust and coconut fiber (among others) has opened new perspectives for the use of these materials as substrate for producing forest seedlings (Trazzi et al., 2014; Silva et al., 2015; Scheer et al., 2012; Rocha et al., 2013). Studies using biosolids (composted sewage sludge) and different structuring materials in the substrate composition have shown positive results for different forest species. In comparing a commercial substrate with others based on different ratios of biosolids and charcoal rice husks in the production of Brazilian Peppertree seedlings (Schinus terebinthifolius Raddi), Trigueiro \& Guerrini (2014) found the best results with proportions of around $40 \%$ biosolids in the mixtures.
At Vale do Ribeira (a peach-palm producing region), Silva et al. (2015) evaluated the viability of using peach-palm agroindustry waste (bark) composted with sewage sludge for the substrate composition, affirming its viability for producing Juçara seedlings (E. edulis Mart.). These results open possibilities for the use of such residues in the composition of substrates; however, even though they are organic materials rich in nutrients, there are no guarantees of their availability during the seedling production cycle. Slow-release fertilizers (SRF) are presented as interesting fertilization alternatives, considering that they have soluble compounds (NPK and some micronutrients) in their formulation that are gradually released due to their composition. SRF have been tested in nurseries and in the field to reduce nutrient losses due to leaching and to reduce post-harvest shock mortality (Lang et al., 2011).

Based on the above, the objectives of this study were to evaluate substrates produced from peach-palm agroindustry residues and sewage sludge as a source of nutrients for the production of Brazilian Peppertree seedlings (Schinus terebinthifolius Raddi), and to compare the performance of these substrates under various levels of slow-release fertilizer for this species.

\section{MATERIAL AND METHODS}

The experiment was carried out in a seedling nursery of the UNESP located in the municipality of Registro, São Paulo state (latitude $24^{\circ} 29^{\prime} 22^{\prime \prime}$ S, longitude $47^{\circ} 50^{\prime} 10^{\prime \prime}$ WE, altitude of $11.99 \mathrm{~m}$ ). The climate is Cf (subtropical humid) according to the Köppen classification.

Three substrates were tested: (1) substrate based on peach-palm (bark) and sewage sludge from the Sewage Treatment Plant of Ilha Comprida, São Paulo state, in the proportion of 1:1 v:v; (2) substrate based on the peach-palm industry waste and compost with sewage sludge in the proportion of 2:1 v:v; and (3) substrate based on the peach-palm industry waste and compost with sewage sludge in the proportion of 3:1 v:v. These potential substrates were named BIOCP I, BIOCP II and BIOCP III. After composting, the samples were collected and sent to laboratories for physical, chemical and biological characterization. 
Characterization of the elements $\mathrm{As}, \mathrm{Cd}, \mathrm{Cr}, \mathrm{Cu}, \mathrm{Hg}$, $\mathrm{Ni}, \mathrm{Pb}, \mathrm{Se}$ and $\mathrm{Zn}$ in the samples was performed using methods 3050 and 3051 as established in the USEPA (2019) (Table 1), and as required by the Resolution No. 375/2006 of the National Environmental Council CONAMA for the characterization of sewage sludge and its by-products (Brasil, 2006). The $\mathrm{pH}$, moisture, total carbon $(\mathrm{C})$, nitrogen $(\mathrm{N})$, phosphorus $(\mathrm{P})$, potassium $(\mathrm{K})$, calcium $(\mathrm{Ca})$, magnesium $(\mathrm{Mg})$, sulfur $(\mathrm{S})$ and sodium $(\mathrm{Na})$ levels were determined according to the methodology proposed by Van Raij et al. (2001). The microbiological analysis was carried out using the methodologies proposed by Higaskino et al. (1998) and Andraus et al. (1998).
Considering the total concentrations of heavy metals and the parasitological parameters (absence of salmonella, fecal coliforms and helminth eggs), the analyzed biosolids were suitable for agricultural use in compliance with CONAMA Resolution No. 375/2006 (Brasil, 2006).

The physical characterization (Table 2) was performed using the methodology proposed by Moraes et al. (2001).

The experiment was conducted in a completely randomized design (CRD) according to a $3 \times 4$ factorial arrangement with three types of substrates (BIOCP I, BIOCP II and BIOCP III) and 4 levels $\left(0 ; 2.0 ; 4.0\right.$ and $\left.6.0 \mathrm{~g} / \mathrm{dm}^{3}\right)$ of slow-release granular fertilizer $\left(\right.$ Osmocote $\left.^{\circledR}\right)\left(\mathrm{N}, \mathrm{P}_{2} \mathrm{O}_{5}, \mathrm{~K}_{2} \mathrm{O}-15-9-12\right)$, with

Table 1. Chemical characterization of the substrates used for Brazilian Peppertree seedling production (Schinus terbinthifolius Raddi).

\begin{tabular}{|c|c|c|c|c|}
\hline Determinations & BIOCPI & BIOCPII & BIOCPIII & Maximus Limits ${ }^{\star *}$ \\
\hline $\mathrm{pH}$ & 5.8 & 6.0 & 6.1 & - \\
\hline $\mathrm{CE}$ & 1.0 & 1.0 & 1.2 & - \\
\hline Relation $\mathrm{C} / \mathrm{N}$ & $11 / 1$ & $10 / 1$ & $11 / 1$ & - \\
\hline $\mathrm{N}(\%)$ & 1.16 & 1.25 & 1.33 & - \\
\hline $\mathrm{P}(\%)$ & 1.01 & 1.01 & 0.9 & - \\
\hline K (\%) & 0.24 & 0.34 & 0.58 & - \\
\hline $\mathrm{Ca}(\%)$ & 0.75 & 0.84 & 0.51 & - \\
\hline $\operatorname{Mg}(\%)$ & 0.75 & 0.84 & 0.52 & - \\
\hline S (\%) & 0.19 & 0.2 & 0.26 & - \\
\hline CTC $\left(\mathrm{mmol}_{\mathrm{c}} \mathrm{kg}^{-1}\right)$ & 405 & 430 & 480 & - \\
\hline $\mathrm{Na}\left(\mathrm{mg} \mathrm{kg}^{-1}\right)$ & 285 & 280 & 307 & - \\
\hline $\mathrm{Cu}\left(\mathrm{mg} \mathrm{kg}^{-1}\right)$ & 31 & 34 & 31 & - \\
\hline $\mathrm{Fe}\left(\mathrm{mg} \mathrm{kg}^{-1}\right)$ & 61275 & 63560 & 57568 & - \\
\hline $\operatorname{Mn}\left(\mathrm{mg} \mathrm{kg}^{-1}\right)$ & 2166 & 2324 & 1799 & - \\
\hline $\mathrm{Zn}\left(\mathrm{mg} \mathrm{kg}^{-1}\right)$ & 164 & 134 & 118 & - \\
\hline $\operatorname{Ar}\left(\mathrm{mg} \mathrm{kg}^{-1}\right)$ & 12.6 & 13.4 & 9.6 & 41 \\
\hline $\mathrm{Cd}\left(\mathrm{mg} \mathrm{kg}^{-1}\right)$ & 15.19 & 13.25 & ND & 39 \\
\hline $\mathrm{Pb}\left(\mathrm{mg} \mathrm{kg}^{-1}\right)$ & 16.05 & 12.65 & 12.7 & 300 \\
\hline $\mathrm{Cr}\left(\mathrm{mg} \mathrm{kg}^{-1}\right)$ & 16.5 & 12.6 & 12.3 & - \\
\hline $\mathrm{Hg}\left(\mathrm{mg} \mathrm{kg}^{-1}\right)$ & 0.22 & 0.24 & 0.12 & 17 \\
\hline $\mathrm{Ni}\left(\mathrm{mg} \mathrm{kg}^{-1}\right)$ & ND & ND & ND & 420 \\
\hline Sel $\left(\mathrm{mg} \mathrm{kg}^{-1}\right)$ & ND & ND & ND & 100 \\
\hline
\end{tabular}

ND $=$ Not detected; ${ }^{* *}$ Maximus limits CONAMA n 375/2006 (Brasil, 2006).

Table 2. Physical characterization of the substrates used for Brazilian Peppertree seedling production (Schinus terbinthifolius Raddi).

\begin{tabular}{|c|c|c|c|c|c|c|}
\hline Substrate & Macroporosity & Microporosity & Total Porosity & WRC & Density & $\begin{array}{l}\text { Particle } \\
\text { density }\end{array}$ \\
\hline & $(\%)$ & $(\%)$ & $(\%)$ & $\mathrm{mL} 50 \mathrm{~cm}^{-3}$ & $\mathrm{~g} \mathrm{~cm}^{-3}$ & $\mathrm{~g} \mathrm{~cm}^{-3}$ \\
\hline BIOCP I & 22.5 & 46.7 & 69.2 & 51.4 & 0.2 & 1.8 \\
\hline BIOCP II & 26.9 & 43.4 & 70.3 & 47.7 & 0.2 & 1.7 \\
\hline BIOCP III & 25.8 & 46.6 & 72.5 & 51.3 & 0.2 & 1.7 \\
\hline
\end{tabular}


a release time between 5 and 6 months. Each treatment was evaluated using four replicates each represented by 20 seedlings and 10 were used for morphological evaluations, thus totaling 40 seedlings per treatment.

Prior to initiating the experiment, the substrates were sieved using a $3 \mathrm{~mm}$ mesh sieve and the granular fertilizer doses were mixed separately for each treatment. Then, $110 \mathrm{~mL}$ cylindrical-conical polyethylene tubes arranged in 192-well plastic trays were filled (with the substrates). Two Brazilian Peppertree seeds were used for the sowing (Schinus terebinthifolius Raddi) per tube. Thinning was performed when the seedlings reached $5 \mathrm{~cm}$ in height, leaving 1 seedling per tube in keeping the most vigorous and centralized one. Irrigations were maintained daily while conducting the experiment using sprinklers with a flow rate of $232 \mathrm{~L} /$ hour, ranging from two to three times in a 4-min watering shift, and depending on the temperature and humidity conditions of the site. No cover fertilization was performed.

Shoot height $(\mathrm{H})$ measurements were performed at 120 days after emergence based on the distance between the stem and the insertion of the last pair of leaves at the apex of the plants, using a graduated ruler in $\mathrm{cm}$ and stem diameter (D) in mm using digital caliper. The H/D ratio was subsequently calculated. The plants were cut at the base of the stem after the measurements, dried in an air circulation oven $\left(60^{\circ} \mathrm{C}\right)$, thus composing the shoot dry matter (SDM). The roots were also separated, washed and dried in an oven at $60^{\circ} \mathrm{C}$, composing the root dry matter (RDM). The SDM was submitted to chemical analysis ( N, P, K, Ca, Mg and S) according to the methodology proposed by Malavolta et al. (1997).

The Dickson Quality Index (DQI) was calculated in order to evaluate the seedling quality according to Equation 1:

$D Q I=$ total dry matter $/(R A D+R B S R)$

in which: RBSR is the relationship between shoot dry biomass and root dry biomass (in $\mathrm{g}$ ); and $R A D$ is the height ratio (in $\mathrm{cm}$ ) with stem diameter (in $\mathrm{mm}$ ).

Data were submitted to analysis of variance and the Tukey mean comparison test (at 5\% probability) using Sisvar software. The levels of one factor within the other were compared for all variables in which interaction between factors was detected. Polynomial regressions were performed with the purpose of analyzing the effect of different levels of fertilizer on the growth of the measured variables.

\section{RESULTS AND DISCUSSION}

A significant effect of the interaction between the different granulated fertilizer doses and the evaluated substrates (Figure 1) was observed for the variables height $(\mathrm{H})$, stem diameter $(\mathrm{D})$, shoot dry matter (SDM) and root dry matter (RDM), as well as nitrogen $(\mathrm{N})$ and potassium $(\mathrm{K})$ leaf contents.

Plant heights presented different behaviors for the three substrates used, as the quadratic responses for BIOCPI and BIOCPII allowed for determining the maximum efficiency of granulated fertilizer doses
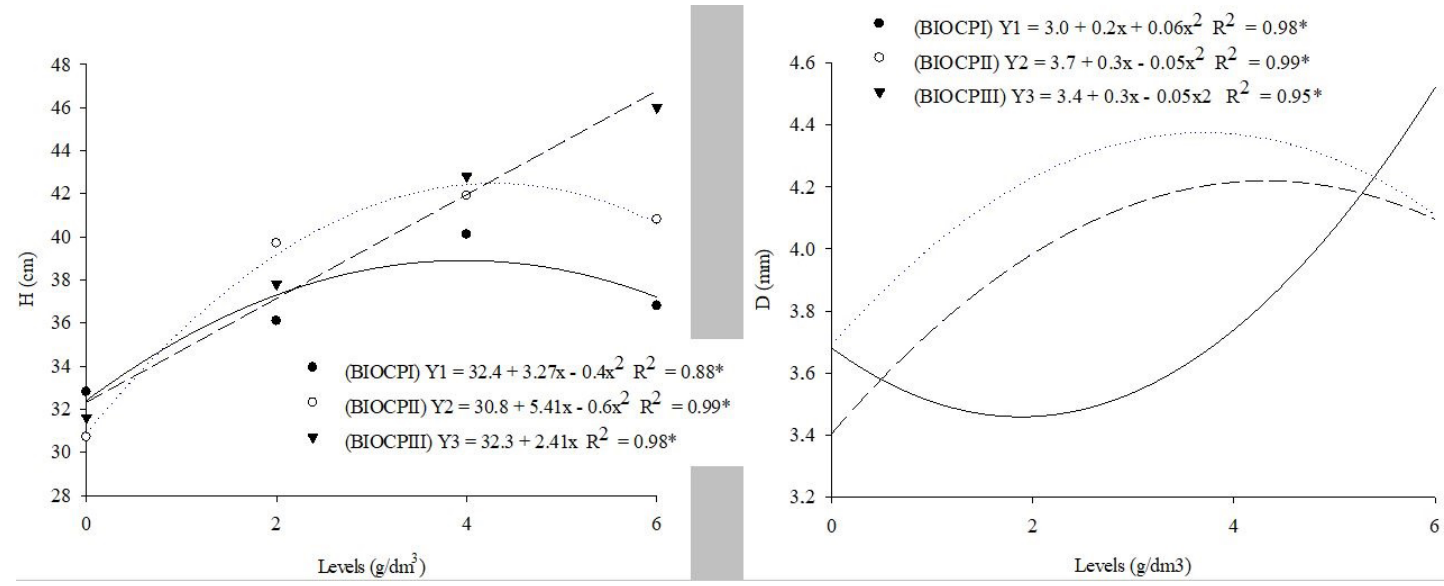

Figure 1. Height $(\mathrm{H})$ and stem diameter (D) of Schinus therebinthipholius Raddi seedlings in three substrates in response to different slow-release fertilizer doses. 
at 4.8 and $4.5 \mathrm{~g} \mathrm{dm}^{-3}$, respectively. The interaction of the BIOCPIII compound with the fertilizer doses showed an increasing linear response, indicating that higher height values could be achieved by using doses higher than $6.0 \mathrm{~g} \mathrm{dm}^{-3}$. In analyzing different doses of a slow-release fertilizer (Osmocote) in the production of Canafístula seedlings (Peltophorul dubium), Dutra et al. (2016) also found positive quadratic responses to an elevation of the fertilizer doses up to the maximum dose of $5.4 \mathrm{~g} \mathrm{dm}^{-3}$.

The seedlings from all treatments presented height between 30 and $40 \mathrm{~cm}$, therefore considered within the standard required for transfer to the field (Table 3). The highest values were obtained by combining the BIOCPIII substrate at the dose of $6.0 \mathrm{~g} \mathrm{dm}^{-3}$. In comparing the substrate averages, BIOCPI was statistically lower than BIOCPII and BIOCPIII; this result may be a reflection of the higher sludge percentages in this substrate's composition. In evaluating increasing proportions of sewage sludge in the production of Brazilian Peppertree seedlings, Trigueiro \& Guerrini (2014) attributed the lower growth in plant height to the higher percentage of sludge in the mixture, being associated to the lower amount of macropores in these treatments with sludge. Nóbrega et al. (2007) found the same tendency as the one observed in the present study; this means a height reduction with percentages greater than $33 \%$ of sludge.

We can also highlight the lower height values when using the three substrates without the addition of granulated fertilizer (level 0), which indicates that these materials alone were not able to meet the nutritional requirements of this species. Gonçalves et al. (1992) found that pioneer species have a more developed root system and a higher density of thin roots, in addition to presenting higher growth rates and nutrient absorption than climax species. Rapid growth and high nutritional requirements thus imply the need for fertilization.

The stem diameter had quadratic behavior for the substrates BIOCPII and BIOCPIII with positive responses up to the maximum dose of $3.0 \mathrm{~g} \mathrm{dm}^{-3}$ (Figure 1). In general, the stem diameter is highly observed in evaluating seedling survival capacity in the field. Thus, it is indicated to help defining the applied fertilizer doses when aiming to evaluate the production and quality of tree seedlings (Carneiro, 1995). As shown in Table 3, it was observed that the seedlings growth on all substrates were above $2.5 \mathrm{~mm}$ at 120 days after germination, including those with no fertilizer addition. Hence they have achieved the recommended standard for transferring to the field with no significant difference between treatment means.

The relationship between height and stem diameter indicates the seedling quality at any stage of the production period, which should be between the limits of 5.4 to 8.1 (Carneiro, 1995). In this study, higher values were verified for the three substrates evaluated in the doses above 2.0 g. $\mathrm{dm}^{-3}$ of the mineral fertilizer (Table 4). Although there was no statistical difference between the evaluated treatments, all of them presented values above this range, which also occurred in the experiment by Trigueiro \& Guerrini (2014) with the same species. The authors point out that the experiment could be finalized before 120 days based on these results.

Shoot dry matter (SDM), root dry matter (RDM) and seedling quality index (DQI) evaluated at 120 days are presented in Table 4 and Figure 2.

Table 3. Height (H), stem diameter (D) and height/diameter ratio (H/D) of Schinus terebinthifolius seedlings at 120 days after germination.

\begin{tabular}{|c|c|c|c|c|c|c|c|c|c|}
\hline \multirow{2}{*}{$\begin{array}{c}\text { Fertiliz. } \\
\left(\text { g. } L^{-1}\right)\end{array}$} & BIOCP I & BIOCP II & BIOCP III & BIOCP I & BIOC II & BIOCP III & BIOCP I & BIOCP II & BIOCP III \\
\hline & \multicolumn{3}{|c|}{$\mathrm{H}(\mathrm{cm})$} & \multicolumn{3}{|c|}{$\mathrm{D}(\mathrm{mm})$} & \multicolumn{3}{|c|}{ H/D } \\
\hline 0 & 32.8 & 30.7 & 31.6 & 3.7 & 3.7 & 3.4 & 8.9 & 8.3 & 7.8 \\
\hline 2 & 36.1 & 39.7 & 37.8 & 3.4 & 4.2 & 4.0 & 10.5 & 9.6 & 9.8 \\
\hline 4 & 40.1 & 41.9 & 42.8 & 3.8 & 4.4 & 4.2 & 10.6 & 9.8 & 10.2 \\
\hline 6 & 36.8 & 40.8 & 46.0 & 4.5 & 4.1 & 4.1 & 8.2 & 10.2 & 11.4 \\
\hline Average & $36.4 \mathrm{~B}$ & $38.2 \mathrm{~A}$ & $39.4 \mathrm{~A}$ & 3.8 & 4.1 & 3.9 & 9.5 & 9.2 & 9.8 \\
\hline \multirow[t]{2}{*}{$\mathrm{VC} \%$} & & 6.8 & & & 10.6 & & & 12.3 & \\
\hline & & * & & & Ns & & & Ns & \\
\hline
\end{tabular}

In the substrates, values in the line followed by the same letter are not significantly different at the Tukey test. Ns = not significant; ${ }^{*}$ significant at $5 \%$ probability level. VC= Variation Coefficient. 
Table 4. Shoot dry matter (SDM), root dry matter (RDM) and Dickson Quality Index (DQI) of Schinus terebinthifolius seedlings at 120 days after germination.

\begin{tabular}{|c|c|c|c|c|c|c|c|c|c|}
\hline \multirow{2}{*}{$\begin{array}{l}\text { Fertilizer } \\
\left(\text { g. } \mathrm{L}^{-1}\right)\end{array}$} & BIOCP I & BIOCP II & BIOCP III & BIOCP I & BIOC II & BIOCP III & BIOCP I & BIOCP II & $\begin{array}{c}\text { BIOCP } \\
\text { III }\end{array}$ \\
\hline & \multicolumn{3}{|c|}{ MSPA (g) } & \multicolumn{3}{|c|}{$\operatorname{MSR}(\mathrm{g})$} & \multicolumn{3}{|c|}{ IQD } \\
\hline 0 & 1.29 & 1.35 & 1.40 & 1.39 & 1.50 & 1.36 & 0.27 & 0.31 & 0.26 \\
\hline 2 & 1.31 & 2.01 & 2.12 & 1.17 & 1.47 & 1.44 & 0.21 & 0.32 & 0.31 \\
\hline 4 & 1.78 & 2.20 & 2.15 & 1.24 & 1.58 & 1.60 & 0.25 & 0.33 & 0.31 \\
\hline 6 & 2.41 & 2.12 & 2.32 & 1.96 & 1.62 & 1.91 & 0.47 & 0.34 & 0.34 \\
\hline Average & $1,69 \mathrm{~B}$ & $1.92 \mathrm{~A}$ & $1.99 \mathrm{~A}$ & $1.44 \mathrm{~B}$ & $1.54 \mathrm{~A}$ & $1.57 \mathrm{~A}$ & 0.30 & 0.32 & 0.30 \\
\hline \multirow[t]{2}{*}{ VC\% } & \multicolumn{3}{|c|}{17.3} & \multicolumn{3}{|c|}{20.6} & \multicolumn{3}{|c|}{21.7} \\
\hline & \multicolumn{3}{|c|}{ * } & \multicolumn{3}{|c|}{ * } & \multicolumn{3}{|c|}{ Ns } \\
\hline
\end{tabular}

In the substrates, values in the line followed by the same letter are not significantly different at the Tukey test. Ns = not significant; $\mathrm{VC}=$ Variation Coefficient; ${ }^{*}$ significant at $5 \%$ probability level.
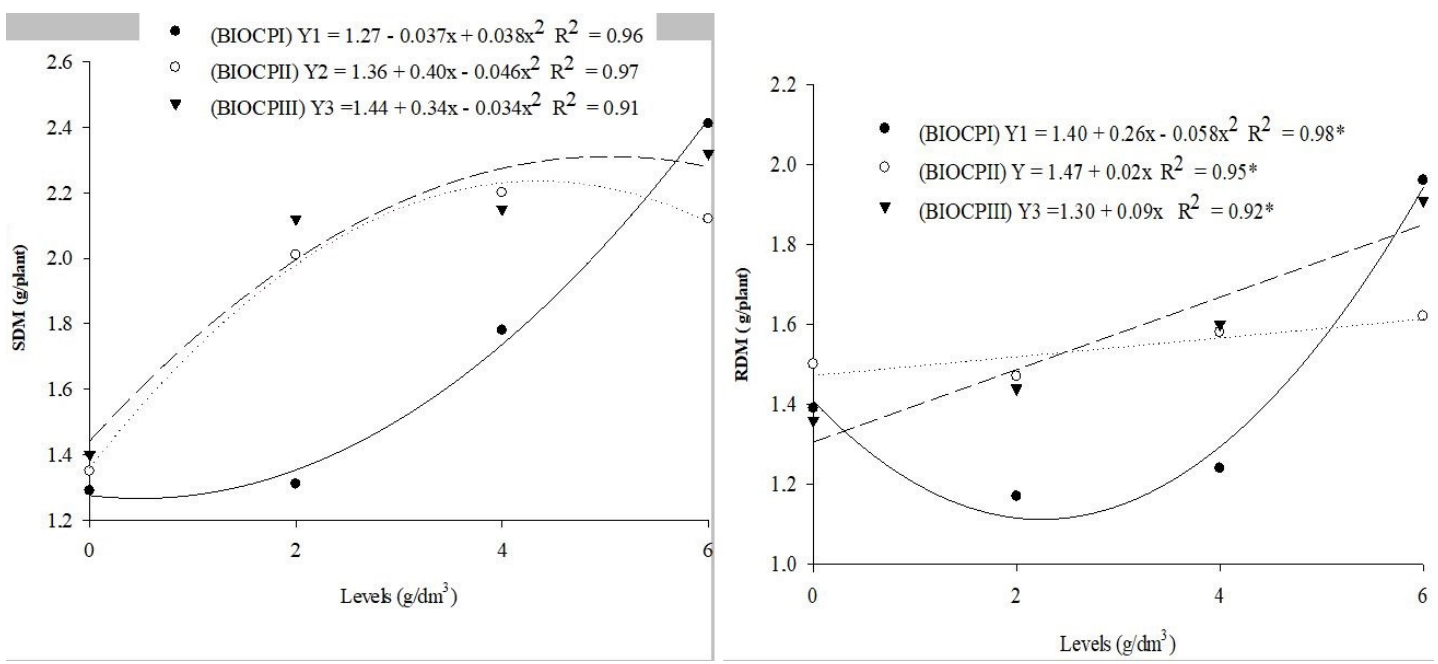

Figure 2. Shoot dry matter (SDM) and root dry matter (RDM) of Schinus therebinthipholius Raddi seedlings on three substrates in response to different doses of the slow-release fertilizer.

Shoot dry matter (SDM) indicates the rusticity of a seedling, with higher values representing more lignified and rustic seedlings and with a greater use in environments with adverse conditions (Gomes \& Paiva, 2004). For the substrates BIOCPII and BIOCPIII (Figure 2), the increasing quadratic equations were adjusted with a maximum calculated dose of 5.0 and $5.6 \mathrm{~g} . \mathrm{dm}^{-3}$, respectively, from which a decrease in production was observed due to a possible saline effect in more eluted doses of the granulated fertilizer. Scheer et al. (2012) observed a tendency to obtain higher biomass values from the shoots of Lafonsia pacari, a non-pioneer species, as the granulated fertilizer was added to sewage sludge-based compounds up to the dose of $2.7 \mathrm{~g} . \mathrm{dm}^{-3}$, followed by a decrease in SDM values. This evidences the difference in nutritional requirements varying with the successional group to which the species belong. The negative quadratic response to the increase of fertilizer doses in the SDM occurred up to the dose of $2.0 \mathrm{~g} \cdot \mathrm{dm}^{-3}$ in the BIOCPI substrate. Similar to that occurring with plant height, the SDM obtained in the substrates BIOCPII and BIOCPIII was significantly superior to the BIOCPI substrate, the treatment based on sewage sludge and peach-palm bark at the proportion of 1:1 (Table 4). Analyzing sewage sludge and carbonized rice hulls as a substrate for the production of eucalyptus, Trigueiro \& Guerrini (2003) found better results for sludge proportions below $50 \%$ of the mixture volume. Studies carried out by Delarmelina et al. (2014), Gomes et al. (2013) and Scheer et al. (2012) have shown results recommending maximum proportions of $60 \%$ of 
sewage sludge in the mixtures. In this study, proportions of $50 \%$ (BIOCPI) of sewage sludge resulted in lower height and SDM values when compared to the other tested substrates. Even from the perspective of the rich mineral composition, the tested substrates were not able to supply the nutritional demands of the Brazilian Peppertree seedlings. The nutrient supply in this stage was provided by the applied slow-release fertilizer.

Incorporating increasing granulated fertilizer doses to the BIOCPII and BIOCPIII substrates (Figure 2) positively influenced the biomass and root (RDM) production of the Brazilian Peppertree, caused by better mineral nutrition in the seedlings.

The use of BIOCP II and BIOCPIII substrates resulted in higher RDM values than that of BIOCPI (Table 4). Trigueiro \& Guerrini (2014) affirm that higher percentages of sewage sludge in the substrate provide lower root growth. This result is associated with the lower percentage of macropores that results in less aeration, as observed in the present study and which can be verified in Table 2 .

Gomes \& Paiva (2004) highlight that the DQI should have a minimum value of 0.20 for quality seedlings. In evaluating this parameter, we verified that all the evaluated materials (Table 4) in this study provided production of quality seedlings. The highest value for the DQI was found with the use of the BIOCPI substrate at the dose of $6.0 \mathrm{~g} \cdot \mathrm{dm}^{-3}$.

The macronutrient contents in the leaves reflect the quality and efficiency in the nutrient supply of the evaluated substrates and the doses of the added slow-release fertilizers. The values obtained were compared with those obtained by Andrade \& Boaretto (2012) regarding the leaf content of nutrients considered suitable for young Brazilian Peppertree plants (Schinus terebinthipholius Raddi) submitted to complete nutrient solution. According to the authors, adequate levels of macronutrients (g/kg) are: $\mathrm{N}(20.0) ; \mathrm{P}(4.2) ; \mathrm{K}(24.0)$; $\mathrm{Ca}$ (10.0); $\mathrm{Mg}$ (2.7); and S (3.3).

The $\mathrm{N}$ contents obtained from the shoots of the seedlings with the substrates BIOCPI and BIOCPII showed an increasing linear response (Figure 3), indicating a positive response to increasing the slow-release fertilizer doses. Comparing the values of Table 5 with those considered as adequate by Andrade \& Boaretto (2012), it is observed that all treatments resulted in low $\mathrm{N}$ foliar content, although no visual symptoms of disability were observed. The similarity in the treatment effects (Table 5) shows that the nutritional differences of the evaluated substrates did not reflect increases in $\mathrm{N}$ content in the shoots of the Brazilian Peppertree seedlings, and that this effect was only due to the doses of added fertilizer. The nutritional richness of these compounds may not have been made available in time, given the nutritional requirement of a pioneer species. By evaluating substrates with different proportions of sewage sludge in the production of Dedaleiro seedlings (Lafoensia pacari), a species of the non-pioneer group, Scheer et al. (2012) found that the $\mathrm{N}$ content present in the compounds were able to supply the nutritional needs of the seedlings 8 months after sowing. In studies using urban waste compost, Berton \& Valadares (1991) reported the need to supplement the compound with
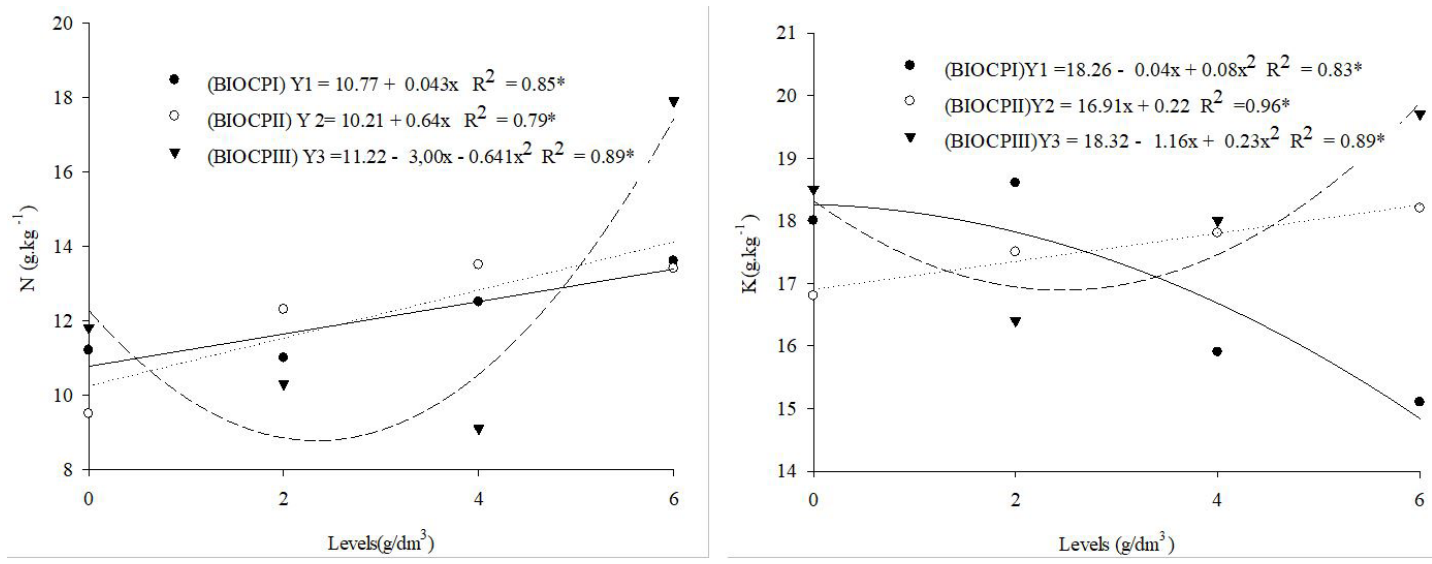

Figure 3. Nitrogen $(\mathrm{N})$ and potassium $(\mathrm{K})$ concentrations in Schinus therebinthipholius Raddi seedlings on three substrates at different doses of the slow-release fertilizer. 
more soluble fertilizers, as the nutrients contained in it are not fully available within the first year.

For the BIOCPI substrate, the maximum dose of 2.0 g. $\mathrm{dm}^{-3}$ fertilizer resulted in the highest levels of $\mathrm{K}$ (Figure 3) in Brazilian Peppertree leaves. The change in the proportion of peach-palm bark in the mixtures resulted in increases in the potassium content in the substrates (Table 1). However, this increase was not reflected in the content of this element in the shoots of the Brazilian Peppertree. No significant differences between the evaluated compounds for the K content in the shoots (Table 5) were verified. All treatments resulted in lower $\mathrm{K}$ content than those observed by Andrade \& Boaretto (2012), which can be attributed to the reduced efficiency when using higher doses of this nutrient.

No interaction between the applied phosphorus doses and the evaluated substrates for the $\mathrm{P}$ content in the shoots of the evaluated plants was found. According to Andrade \& Boaretto (2012), all values observed in this study are below those considered appropriate for the species. Although some other authors (Scheer, 2010; Rocha et al., 2013) have credited the capacity of compounds obtained from sewage sludge and residues such as rice husk and tree pruning used pure (without the addition of fertilizers) to meet the nutritional needs of seedlings, these results may vary according to the different species. $P$ content found in the sewage sludge, as well as in the compounds obtained by the mixture of this material with other waste, does not ensure greater availability for the seedlings in the early stages of growth. This element can be mineralized over time, which may represent nutritional deficiencies for fast growing species with high nutritional requirements.

$\mathrm{Ca}, \mathrm{Mg}$ and $\mathrm{S}$ contents in the shoots of the Brazilian Peppertree seedlings (Table 6) did not statistically differ between the doses or the compounds tested. Although lower than those considered suitable for seedlings of this species, the values are close to those observed in experiments using sewage sludge

Table 5. Nitrogen $(\mathrm{N})$, phosphorus $(\mathrm{P})$ and potassium $(\mathrm{K})$ concentrations in the shoots of Schinus terebinthifolius seedlings at 120 days.

\begin{tabular}{|c|c|c|c|c|c|c|c|c|c|}
\hline \multirow{3}{*}{ 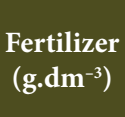 } & BIOCP I & BIOCP II & BIOCP III & BIOCP I & BIOCP II & BIOCP III & BIOCP I & BIOCP II & BIOCP III \\
\hline & \multicolumn{3}{|c|}{$\mathbf{N}$} & \multicolumn{3}{|c|}{$\mathbf{P}$} & \multicolumn{3}{|c|}{$\mathbf{K}$} \\
\hline & \multicolumn{9}{|c|}{--------------------------------- $($ g.kg '1) -------------------------------- } \\
\hline 0 & 11.2 & 9.5 & 11.8 & 1.7 & 1.6 & 1.8 & 18.0 & 16.8 & 18.5 \\
\hline 2 & 11.0 & 12.3 & 10.3 & 1.7 & 1.7 & 1.7 & 18.6 & 17.5 & 16.4 \\
\hline 4 & 12.5 & 13.5 & 9.1 & 1.4 & 1.5 & 1.9 & 15.9 & 17.8 & 18.0 \\
\hline 6 & 13.6 & 13.4 & 17.9 & 1.4 & 1.6 & 1.9 & 16.5 & 18.2 & 19.7 \\
\hline Average & 12.0 & 12.1 & 12.2 & 1.5 & 1.6 & 1.8 & 17.2 & 17.5 & 18.1 \\
\hline \multirow[t]{2}{*}{ VC (\%) } & & 16.0 & & & 11.2 & & & 18.3 & \\
\hline & & Ns & & & Ns & & & Ns & \\
\hline
\end{tabular}

In the substrates, values in the line followed by the same letter are not significantly different at the Tukey test. Ns = not significant; $\mathrm{VC}=$ Variation Coefficient.

Table 6. Calcium $(\mathrm{Ca})$, magnesium $(\mathrm{Mg})$ and sulfur $(\mathrm{S})$ contents in shoots of Schinus terebinthifolius seedlings at 120 days.

\begin{tabular}{|c|c|c|c|c|c|c|c|c|c|}
\hline \multirow{3}{*}{$\begin{array}{c}\text { Fertilizer } \\
(\text { g.dm } \\
-3)\end{array}$} & BIOCP I & BIOCP II & BIOCP III & BIOCP I & BIOC II & BIOCP III & BIOCP I & BIOCP II & BIOCP III \\
\hline & \multicolumn{3}{|c|}{$\mathrm{Ca}$} & \multicolumn{3}{|c|}{ Mg } & \multicolumn{3}{|c|}{$\mathbf{S}$} \\
\hline & \multicolumn{9}{|c|}{ 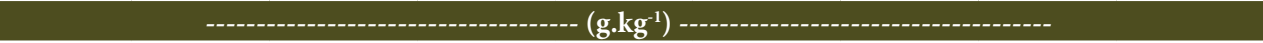 } \\
\hline 0 & 9.7 & 9.2 & 8.6 & 2.0 & 2.2 & 2.2 & 1.8 & 1.8 & 2.0 \\
\hline 2 & 9.9 & 8.7 & 8.8 & 2.2 & 2.1 & 2.1 & 1.8 & 1.8 & 1.9 \\
\hline 4 & 8.7 & 8.3 & 8.1 & 2.2 & 2.1 & 2.1 & 1.9 & 1.9 & 1.9 \\
\hline 6 & 8.4 & 10.1 & 9.6 & 2.0 & 2.6 & 2.4 & 1.9 & 1.9 & 2.0 \\
\hline Average & 9.1 & 9.0 & 8.7 & 2.1 & 2.2 & 2.2 & 1.8 & 1.8 & 1.9 \\
\hline \multirow[t]{2}{*}{ VC (\%) } & & 17.7 & & & 7.9 & & & 8.1 & \\
\hline & & Ns & & & Ns & & & Ns & \\
\hline
\end{tabular}

In the substrates, values in the line followed by the same letter are not significantly different at the Tukey test. Ns $=$ not significant. $\mathrm{VC}=$ Variation Coefficient. 
(Trigueiro \& Guerrini, 2014). However, the seedlings did not present any symptom of nutritional deficiency for these elements throughout the experiment.

The substrates obtained from residues such as peach-palm and sewage sludge present viability for producing Brazilian Peppertree seedlings. However, the species' successional group must be taken into account. In the case of pioneer species, the short planting time implies the need for nutrient supply via more soluble sources applied via ferti-irrigation or even the use of granular slow-release fertilizers.

The results presented in this study attest to the positive effect of mixing peach-palm agroindustry waste to sewage sludge for producing substrates and quality seedlings. The production of these materials on a larger scale can thus bring economic and environmental gains, since it meets the recycling criteria of waste with polluting potential.

\section{CONCLUSIONS}

When used pure, the BIOCPI, BIOCPII and BIOCPIII substrates were not able to supply the necessary nutrients for the growth of the Brazilian Peppertree.

The use of the substrates BIOCPII and BIOCPIII produced from sewage sludge and peach-palm agroindustry residue was viable for the production of Brazilian Peppertree seedlings. Doses above $4.0 \mathrm{gdm}^{-3}$ of granulated fertilizer are recommended.

\section{ACKNOWLEDGEMENTS}

The authors would like to thank FAPESP (Pr. no 2011/01581-1).

\section{SUBMISSION STATUS}

Received: 31 oct., 2017

Accepted: 19 jan., 2018

\section{CORRESPONDENCE TO}

\section{Francisca Alcivania Melo Silva}

Universidade Estadual Paulista "Júlio de Mesquita Filho" - UNESP, Av. Nelson Brihi Badur, CEP 11900-000, Registro, SP, Brasil e-mail: alcivania@registro.unesp.br

\section{FINANCIAL SUPPORT}

Fundação de Amparo à Pesquisa do Estado de São Paulo FAPESP (Pr. n² 2011/01581-1).

\section{REFERENCES}

Andrade ML, Boaretto AE. Deficiência nutricional em plantas jovens de aroeira-pimenteira (Schinus terebinthifolius Raddi). Scientia Forestalis 2012; 21(12): 383-392.

Andraus S, Medeiros MLB, Borges JC, Silva SMCP, Toledo EBS. Pesquisa de Salmonella spp. em amostras de lodo de esgoto e solo: isolamento e identificação. In: Andreoli CV, Bonnet BRP, editores. Manual de métodos para análises microbiológicas e parasitológicas em reciclagem agrícola de lodo de esgoto. Curitiba: Sanepar; 1998. p. 59-61.

Berton RS, Valadares JMAS. Potencial agrícola do composto de lixo urbano no Estado de São Paulo. Agronômico 1991; 43: 87-93.

Brasil. Ministério do Meio Ambiente. Conselho Nacional do Meio Ambiente. Resolução no 375, de 29 de agosto de 2006. Define critérios e procedimentos, para o uso agrícola de lodos de esgoto gerados em estações de tratamento de esgoto sanitário e seus produtos derivados, e dá outras providências. Diário Oficial da República Federativa do Brasil [online], Brasília, DF (2006 ago. 30) [cited 2013 Mar 25]. Available from: http://www.mma.gov.br/port/ conama/res/res06/res37506.pdf

Caldeira MVW, Wendling I, Penchel RM, Gonçalves EO, Kratz D, Trazzi PA. Propriedades de substratos para produção de mudas florestais. In: Caldeira MVW, Garcia GO, Gonçalves EO, Arantes MDC, Fiedler NC, editors. Contexto e perspectivas da área florestal no Brasil. Alegre: Suprema; 2011.

Carneiro JGA. Produção e controle de qualidade de mudas florestais. Curitiba: Universidade Federal do Paraná; 1995.

Delarmelina WM, Caldeira MVW, Faria JCT, Gonçalves EO, Rocha RLF. Diferentes substratos para a produção de mudas de Sesbania virgata. Floresta e Ambiente 2014; 21(2): 224-233. http://dx.doi.org/10.4322/floram.2014.027.

Dutra TR, Massad MD, Sarmento MFQ, Matos PS, Oliveira JC. Fertilizante de liberação lenta no crescimento e qualidade de mudas de canafístula (Peltophorum dubium). Floresta 2016; 46(4): 491-498. http://dx.doi.org/10.5380/ rf.v46i4.44570.

Fleig M, Klein RM. Anacardiáceas: flora ilustrada catarinense. Itajaí: Herbário Barbosa Rodrigues; 1989.

Gomes DR, Caldeira MVW, Delarmelina WM, Gonçalves EO, Trazzi PA. Lodo de esgoto como substrato para produção de mudas de Tectona grandis L. Revista Ceres 2013; 19(1): 123-131. 
Gomes JM, Paiva HN. Viveiros florestais: propagação sexuada. 3. ed. Viçosa: UFV; 2004. (Caderno Didático).

Gonçalves JLM, Freixedas VM, Kageyama PY, Gonçalves JC, Dias JHP. Produção de biomassa e sistema radicular de espécies de diferentes estágios sucessionais. Revista do Instituto Florestal 1992; 4: 363-367.

Higaskino CEK, Takamatsu AA, Borges JC, Baldin SM. Determinação de coliformes fecais em amostras de lodo de esgoto por fermentação em tubos múltiplos. In: Andreoli $\mathrm{CV}$, Bonnet BRP, editores. Manual de métodos para análises microbiológicas e parasitológicas em reciclagem agrícola de lodo de esgoto. Curitiba: Sanepar; 1998.

Lang A, Malavasi UC, Decker V, Pérez PV, Aleixo MA, Malavasi MM. Aplicação de fertilizante de liberação lenta no estabelecimento de mudas de ipê-roxo e angico-branco em área de domínio ciliar. Revista Floresta 2011; 41(2): 271-276. http://dx.doi.org/10.5380/rf.v41i2.21874.

Lenzi M, Orth AI. Caracterização funcional do sistema reprodutivo da aroeira-vermelha (Schinus terebinthifolius Raddi), em Florianópolis, SC, Brasil. Revista Brasileira de Fruticultura 2004; 26(2): 198-201. http://dx.doi.org/10.1590/ S0100-29452004000200004.

Malavolta E, Vitti GC, Oliveira AS. Avaliação do estado nutricional das plantas: princípios e aplicações. Piracicaba: Potafos; 1997.

Moraes SP No, Gonçalves MLJ, Souza MP. Produção de mudas de seis espécies arbóreas, que ocorrem nos domínios da floresta atlântica, com diferentes substratos de cultivo e níveis de luminosidade. Revista Árvore 2001; 25(3): 277-287.

Nóbrega RSA, Boas RCV, Nóbrega JCA, Paula AM, Moreira FMS. Utilização de biossólido no crescimento inicial de mudas de aroeira (Schinus terebinthifolius Raddi). Revista Árvore 2007; 31(2): 239-246. http://dx.doi.org/10.1590/ S0100-67622007000200006.
Rocha JHT, Backes J, Diogo FA, Pascotto CB, Borelli K. Composto de lodo de esgoto como substrato para mudas de eucalipto. Pesquisa Florestal Brasileira 2013; 33(73): 27-35. http://dx.doi.org/10.4336/2013.pfb.33.73.331.

Scheer MB, Carneiro C, Santos KG. Crescimento de mudas de Prunus brasiliensis (Cham. \& Schltdl.) D. Dietr. em substratos à base de lodo de esgoto compostado e fertilizante mineral. Ciência Florestal 2012; 22(4): 739 747. http://dx.doi.org/10.5902/198050987555.

Scheer MB. Substratos à base de lodo de esgoto compostado na produção de mudas de Parapiptadenia rígida. Scientia Forestalis 2010; 38: 637-644.

Silva FAM, Souza IV, Zanon JA, Nunes GM, Silva RB, Ferrari S. Produção de mudas de juçara com resíduos agroindustriais e lodo de esgoto compostados. Revista Brasileira de Engenharia de Biossistemas 2015; 9(2): 109121. http://dx.doi.org/10.18011/bioeng2015v9n2p109-121.

Trazzi PA, Caldeira MVW, Reis EF, Silva AG. Produção de mudas de Tectona grandis em substratos formulados com biossólido. Cerne 2014; 20(2): 293-302. http://dx.doi. org/10.1590/01047760.201420021134.

Trigueiro RM, Guerrini IA. Uso de biossólidos como substrato para produção de mudas de eucalipto. Scientia Forestalis 2003; 64: 150-162.

Trigueiro RM, Guerrini IA. Utilização de lodo de esgoto na produção de mudas de Aroreira-pimenteira. Revista Árvore 2014; 38(4): 657-665. http://dx.doi.org/10.1590/ S0100-67622014000400009.

U.S. Environmental Protection Agency - USEPA. SW-846: test methods for evaluating solid waste: physical/chemical methods [online]. Washington: USEPA; 2019 [cited 2019 May 14]. Available from: https://www.epa.gov/hw-sw846/ sw-846-compendium

Van Raij B, Andrade JC, Cantarella H, Quaggio JA. Análise química para avaliação da fertilidade de solos tropicais. Campinas: Instituto Agronômico; 2001. 285 p. 